\title{
Karakteristik Minyak Jarak Pagar (Jatropha curcas L) Epoksi Murni Sebagai Pelunak Vulkanisat Karet NBR
}

\author{
The Characteristic of Pure Epoxidized Jatropha Curcas (Jatropha curcas L.) Oil as \\ NBR Vulcanizate Plasticizer
}

\author{
Norma A. KINASIH dan Adi CIFRIADI \\ Pusat Penelitian Karet \\ Jalan Salak No. 1 Bogor 16151 Bogor \\ Email: norma.kinasih88@gmail.com
}

Diterima : 9 Mei 2014 / Direvisi : 11 Juni 2014 / Disetujui : 19 Juli 2014

\begin{abstract}
The utilizing of phtalat group plasticizer on NBR such as; dioctil phatalat (DOP), diisononil phatalat (DINP) and diisodecil phatalat (DIDP) has been controled because of their impact on environment contamination and health damage. One of the alternative substitute phtalat group plasticizer is epoxidized jatropha curcas oil. The side reactions was formed during epoxidation reaction, which could decrease the quality of epoxidized jatropha curcas oil. The purpose of the research is to investigate the influence of purification processs on epoxidized jatropha curcas oil characteristics and the application on NBR vulcanizate. The utilization of pure epoxidized jatropha curcas oil on NBR vulcanizate will be compare with impure epoxidized jatropha curcas oil by impure of epoxidized jatropha curcas oil and DOP, which were used in 5phr dosages respectively. The characterization of pure epoxidized jatropha curcas oil was analyzed by quantitative (oxirane number and \% epoxidized) and qualitative (FTIR). Meanwhile the characterization of NBR vulcanizate showed by a result of physical properties test. The yield of purification process was $82,94 \%$. The characterization of pure epoxidized jatropha curcas oil showed that purification process reduced all of side reaction-products of epoxidation process. Pure epoxy jatropha curcas oil reduced The best ability on the reducing hardness of NBR rubber are the used of impure epoxidized jatropha curcas oil (A), followed by the pure epoxidized jatropha curcas oil (B) and DOP $(C)$.
\end{abstract}

Keywords: Plasticizer, epoxidized jatropha curcas oil, DOP, NBR

\section{Abstrak}

Penggunaan bahan pelunak kelompok phtalat pada karet NBR seperti dioktil ftalat (DOP), diisononil ftalat (DINP) dan diisodekil ftalat (DIDP) mulai dibatasi, karena merusak lingkungan dan kesehatan. Salah satu bahan pelunak alternatif yang digunakan adalah minyak jarak pagar epoksi. Selama berlangsungnya reaksi epoksidasi, terbentuk reaksi samping yang dapat menurunkan kualitas minyak jarak pagar epoksi. Pemurnian perlu dilakukan untuk menjaga kualitas kandungan oksiran minyak jarak pagar. Penelitian dilakukan untuk mengetahui pengaruh pemurnian terhadap kualitas minyak jarak pagar epoksi dan peggunaannya sebagai pelunak pada vulkanisat karet NBR. Kemampuan minyak jarak pagar epoksi murni sebagai pelunak karet NBR diuji dengan membandingkan kinerjanya dengan minyak jarak pagar epoksi sebelum pemurnian dan DOP menggunakan dosis yang sama, yaitu 5 bsk . Karakteristik minyak jarak pagar epoksi sebelum dan setelah pemurnian dianalisa secara kuantitatif (nilai oksiran dan \% terepoksidasi) dan kualitatif (FTIR). Karakterisasi vulkanisat karet NBR ditunjukkan melalui hasil pengujian sifat fisiknya. Rendemen minyak hasil perlakuan pemurnian sebesar 82,94\%. Hasil karakteristik minyak jarak pagar epoksi menunjukkan bahwa perlakuan pemurnian mampu menurunkan hasil samping reaksi epoksidasi. Kemampuan yang lebih baik dalam menurunkan kekerasan karet NBR secara berturut-turut dimulai dari minyak jarak pagar sebelum pemurnian (A), diikuti minyak jarak pagar setelah pemurnian (B) dan $\operatorname{DOP}(\mathrm{C})$.

Kata kunci: Pelunak, minyak jarak pagar epoksi, DOP, NBR

\section{PENDAHULUAN}

Penggunaan pelunak pada karet NBR dan plastik PVC umumnya menggunakan kelompok ftalat, yang berbahan dasar minyak bumi. Sekitar 80\% kebutuhan dunia menggunakan dioktil ftalat (DOP), diisononil ftalat (DINP) dan diisodecil ftalat (DIDP) (Karaukoph dan Godwin, 2005). Namun penggunaan pelunak jenis ini mulai ditinggalkan karena pelunak jenis ftalat dinilai berbahaya, dapat bermigrasi ke lingkungan (Yu, 2005 dalam Greco et al., 2010) dan mengganggu kesehatan seperti menyebabkan cacat pada janin, kanker, dan terganggunya sistem reproduksi (James et al., 1975 dan Awang 1995 dalam 
Saefurohman, 2008). EPA'sToxic Release Inventory menggolongakan ftalat sebagai senyawa toksik. Bahkan mulai tahun 2006, Uni Eropa telah mengeluarkan larangan penggunaan jenis ester ftalat (Tullo, 2005).

Salah satu alternatif pelunak yang dapat menggantikan pelunak jenis ini adalah minyak nabati epoksi. Beberapa studi melaporkan bahwa minyak nabati epoksi mampu digunakan sebagai pelunak dalam karet NBR (Riyanti, 1992) dan PVC baik sebagai pelunak dan penstabil tambahan (secondary plasticizer and stabilizer) ataupun pelunak utama (primary plasticizer) (Gall dan Greenspan, 1958; Gan et al., 1994; dan Karmalam et al., 2009). Selain itu penggunaan pemlastis berbahan dasar minyak nabati memiliki keunggulan yaitu berbahan dasar terbarukan dan bersifat alami sehingga aman untuk lingkungan dan kesehatan.

Reaksi epoksidasi adalah reaksi antara asam peroksi organik dan senyawa yang berikatan rangkap (termasuk asam lemak tak jenuh dalam minyak nabati) untuk membentuk senyawa oksiran (epoksida). Selama berlangsungnya reaksi tersebut akan terbentuk reaksi samping yang bersifat asam dan dapat menyebabkan pembukaan cincin oksiran (Petrovic et al., 2002), sehingga harus dihilangkan dari reaksi. Karmalm et al. (2009) menyatakan bahwa peningkatan nilai oksiran minyak kedelai epoksi dapat meningkatkan waktu penggunaan plasticizer pada matriks PVC. Dalam rangka untuk melihat lebih jauh karakteristik minyak jarak epoksi, maka pada kegiatan ini akan diteliti pengaruh pemurnian terhadap kualitas minyak jarak pagar epoksi dan peggunaannya sebagai pelunak pada vulkanisat karet NBR.

\section{BAHAN DAN METODE}

Penelitian dilaksanakan di Laboratorium penelitian Pusat Penelitian Karet pada bulan Januari-Mei tahun 2013. Bahan-bahan yang digunakan pada penelitian ini antara lain: minyak jarak pagar (nilai iod 40,5 $\mathrm{gI}_{2} / 100 \mathrm{~g}$ ), asam format (47\%), hidrogen peroksida (47\%), asam sulfat $(98 \%)$, aquades dan larutan $\mathrm{Na}_{2} \mathrm{CO}_{3}$. Alat-alat yang dibutuhkan untuk analisa, proses reaksi epoksidasi dan pemurnian antara lain; piknometer, biuret, erlenmeyer 100 dan $250 \mathrm{ml}$, waterbath, magnetic stirer, labu leher tiga, termokopel, soklet modifikasi dan gelas piala 150 dan $500 \mathrm{ml}$.

\section{Reaksi Epoksidasi dan Pemurnian Minyak Jarak Pagar Epoksi}

Reaksi epoksidasi minyak jarak pagar dilakukan secara insitu menggunakan asam perkarboksilat. Minyak jarak pagar direaksikan dengan pereaksi asam format dan hidrogen peroksida dengan perbandingan mol C=C : $\mathrm{HCOOH}: \mathrm{H}_{2} \mathrm{O}_{2}$ sebesar 0,214:0,107:0,428 mol (Hawash et al., 2011). Reaksi epoksidasi berlangsung pada suhu $40,50,60$ dan $70^{\circ} \mathrm{C}$ selama $1,3,5$ dan 7 jam di dalam labu leher tiga. Suhu dipertahankan pada waktu reaksi tersebut menggunakan waterbath dan dikontrol menggunakan termokopel.

Minyak jarak pagar epoksi yang dihasilkan kemudian dipisahkan dengan reaksi sampingnya melalui pencucian bertahap menggunakan corong pemisah. Minyak jarak pagar epoksi dicuci menggunakan aquades pada suhu $30^{\circ} \mathrm{C}$ sebanyak lima kali dan aquades pada suhu $50^{\circ} \mathrm{C}$ sebanyak tiga kali. Masing-masing pencucian berselang selama 15 menit. Pemurnian kemudian dilanjutkan dengan penambahan larutan $\mathrm{Na}_{2} \mathrm{CO}_{3}\left(\mathrm{~T}=50^{\circ} \mathrm{C}\right.$ ) (Pérez, et al., 2009). Minyak jarak pagar epoksi didiamkan selama 1 jam dalam larutan tersebut, kemudian dipisahkan.

\section{Analisis minyak jarak pagar epoksi murni}

Minyak Jarak Pagar Epoksi sebelum dan sesudah pemurnian dianalisis secara kualitatif menggunakan FTIR dan secara kuantitatif dengan menghitung nilai oksiran dan \% terepoksidasi yang terbentuk menggunakan rumus berikut (Pérez, et al., 2009):

$$
\% \text { Oksiran }=\frac{\mathrm{ml} \text { titrasi } \operatorname{HBr} \times \mathrm{N} \mathrm{HBr}(0,1) \times 1,60}{\text { berat sampel }(\mathrm{g})}
$$

$\%$ terepoksi $=\frac{\text { OOe (nilai oksiran hasil eksperiment) }}{\text { OOp (nilai oksiran optimum yang dapat dicapai) }} \times 100 \%$

$$
\mathrm{OOp}=\left[\frac{\frac{16 \varnothing}{2 \mathrm{Ai}}}{\left(100+\ddot{\mathrm{A}} \frac{12 \mathrm{Ai}}{2 \mathrm{~A} A o}\right.}\right] \dot{A} \times \text { Ao } \times 100
$$

Dimana $\mathrm{IVo}=$ nilai iod minyak awal hasil uji, $\mathrm{Ai}=\mathrm{Mr} \operatorname{iod}(126,9), \mathrm{Ao}=\mathrm{Ar}$ Oksigen $(16,0)$ 


\section{Pembuatan Kompon Karet NBR}

Minyak jarak pagar epoksi terbaik sebelum pemurnian mengandung 72,31\% terepoksidasi (kompon A) diaplikasikan pada pembuatan karet NBR. Sebagai pembanding digunakan kompon $\mathrm{B}$ dan $\mathrm{C}$ yang menggunakan minyak jarak pagar setelah pemurnian mengandung $78,09 \%$ terepoksidasi dan DOP (Cifriadi dan Kinasih, 2013). Susunan resep kompon karet NBR disajikan pada Tabel 1 .

\section{Pengujian Sifat Fisika}

Formulasi kompon karet tersebut kemudian digiling menggunakan mesin giling terbuka (open mill). Kompon karet divulkanisasi menggunakan sistem semi konvensional pada suhu $150^{\circ} \mathrm{C}$ selama waktu tertentu (sesuai hasil pengujian rheometer). Vulkanisat karet kemudian dianalisis sifat fisikanya berdasarkan uji ASTM. Parameter fisika yang diuji meliputi; kekerasan (D2240-05), tegangan putus, perpanjangan putus, modulus $200 \%$ (D41206 Ae 2), ketahanan sobek (D624-00), berat jenis, dan pemampatan tetap 25\% selama 72 jam pada suhu ruang dan $70^{\circ} \mathrm{C}$ (D39503).

\section{HASIL DAN PEMBAHASAN}

\section{Analisa Kuantitatif Minyak Jarak Pagar Epoksi Murni}

Pengujian kuantitatif minyak jarak pagar epoksi menunjukkan bahwa nilai oksiran dan \% terepoksidasi semakin meningkat seiring dengan penambahan waktu dan suhu. Peningkatan nilai oksiran dan \% terepoksidasi juga terjadi setelah pemurnian. Nilai optimum oksiran dan \% terepoksidasi minyak jarak pagar epoksi murni tercapai pada suhu $60^{\circ} \mathrm{C}$ selama 7 jam reaksi. Optimasi nilai oksiran dan \% terepoksidasi minyak jarak pagar epoksi murni disajikan pada Gambar 1 dan 2. Peningkatan nilai oksiran dan \% terepoksi menunjukkan cenderung menurun ketika mencapai kondisi optimum. Hal ini dapat disebabkan karena setelah mencapai titik maksimum terdapat kemungkinan adanya reaksi antara gugus oksiran dengan reaktan (asam perasetat dan hidrogen peroksida) yang mengakibatkan kandungan oksiran yang telah terbentuk menjadi berkurang (Petrovic et al., 2002).

Hasil analisa statistik menggunakan uji Duncan menunjukkan bahwa kombinasi perlakuan suhu $60^{\circ} \mathrm{C}$ dan waktu 7 jam paling efektif meningkatkan nilai oksiran dan \% terepoksidasi minyak jarak pagar sebelum dan setelah pemurnian. Kombinasi perlakuan suhu $60^{\circ} \mathrm{C}$ dan waktu 7 jam terhadap nilai \% terepoksidasi minyak jarak pagar epoksi sebelum pemurnian menunjukkan tidak berbeda nyata terhadap nilai \% terepoksidasi hasil kombinasi perlakuan suhu $40^{\circ} \mathrm{C}$ dan waktu 5 jam dan suhu $60^{\circ} \mathrm{C}$ dan waktu 5 jam, serta berbeda nyata terhadap kombinasi perlakuan yang lain. Kombinasi perlakuan suhu $60^{\circ} \mathrm{C}$ dan waktu 7 jam terhadap nilai \% terepoksidasi minyak jarak pagar epoksi setelah pemurnian menunjukkan tidak berbeda

Tabel 1. Formula kompon karet NBR

Table 1. NBR compound formula

\begin{tabular}{|c|c|c|c|}
\hline \multirow[t]{2}{*}{$\begin{array}{l}\text { Bahan } \\
\text { Material }\end{array}$} & \multicolumn{3}{|c|}{$\begin{array}{c}\text { Dosis } \\
\text { (bsk) } \\
\text { Dosage } \\
\text { (phr) }\end{array}$} \\
\hline & $\mathrm{A}$ & $\mathrm{B}$ & $\mathrm{C}$ \\
\hline NBR & 100 & 100 & 100 \\
\hline $\mathrm{ZnO}$ & 5 & 5 & 5 \\
\hline Asam Stearat & 2 & 2 & 2 \\
\hline Carbon black (N330) & 40 & 40 & 40 \\
\hline TBBS & 1 & 1 & 1 \\
\hline TMTD & 0,5 & 0,5 & 0,5 \\
\hline Sulfur & 1,5 & 1,5 & 1,5 \\
\hline TMQ & 1 & 1 & 1 \\
\hline Minyak jarak epoksi $(72,31 \%)$ & 5 & 0 & 0 \\
\hline Minyak jarak epoksi murni $(78,09 \%)$ & 0 & 5 & 0 \\
\hline DOP (Dioctil phatalat) & 0 & 0 & 5 \\
\hline
\end{tabular}




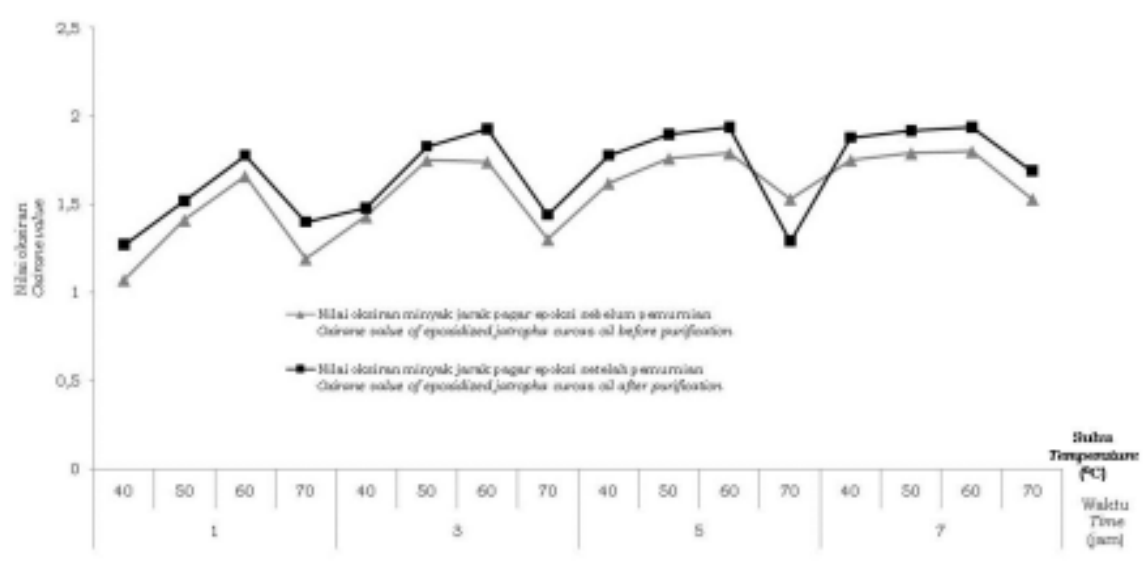

Gambar 1. Nilai oksiran minyak jarak pagar epoksi

Figure 1. Oxirane number of epoxidized Jatropha curcas oil

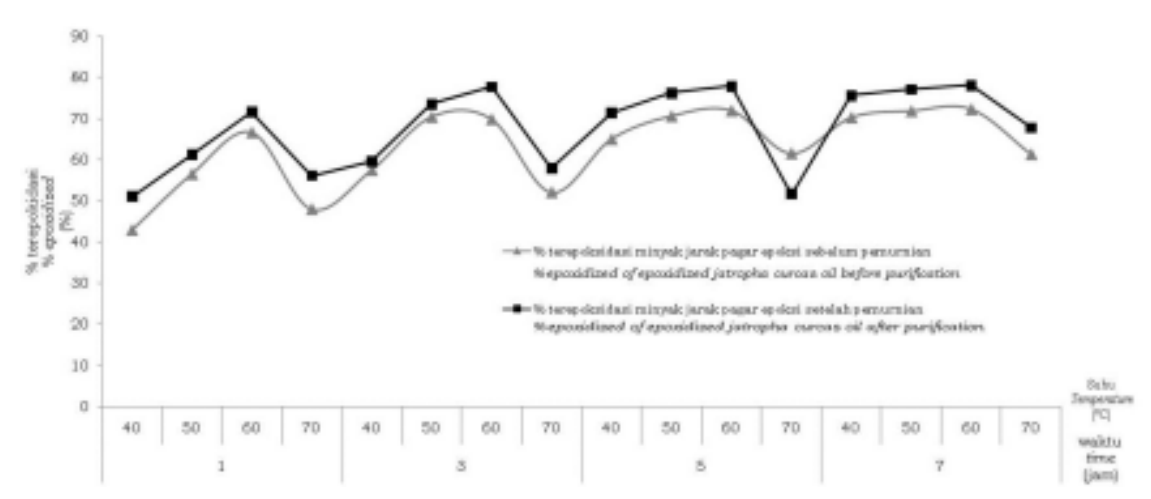

Gambar 2. Nilai \% terepoksidasi minyak jarak pagar epoksi

Figure 2. \% epoxidized of epoxidized jatropha curcas oil

nyata terhadap nilai \% terepoksidasi hasil kombinasi perlakuan suhu $40^{\circ} \mathrm{C}$ dan waktu 5 jam dan berbeda nyata terhadap kombinasi perlakuan yang lain.

Pemurnian bermaksud untuk menghilangkan reaksi samping selama berlangsungnya reaksi epoksidasi. Beberapa reaksi samping yang terbentuk antara lain; air, asam format/asam asetat yang berlebih, hidrogen peroksida yang berlebih, dan minyak nabati yang tidak bereaksi. Reaksi samping tersebut dapat menyebabkan pembukaan cincin oksiran (Petrovic et al., 2001), sehingga harus dihilangkan dari reaksi karena bersifat asam (Gamage et al., 2009). Penghilangan reaksi samping dapat meminimalisir terbukanya cincin oksiran, sehingga nilai oksiran dan \% terepoksidasi meningkat setelah dimurnikan.

\section{Analisa Kualititatif Minyak Jarak Pagar Epoksi Murni}

Analisa karakteristik minyak jarak pagar epoksi murni secara kualitatif menunjukkan bahwa terdapat perubahan karakteristik minyak jarak pagar epoksi sebelum dan setselah dimurnikan. Terjadinya reaksi epoksidasi membuka ikatan rangkap (termasuk asam lemak tak jenuh dalam minyak nabati) menjadi senyawa oksiran (epoksida), sehingga nilai iod minyak jarak pagar menurun seiring peningkatan nilai oksirannya.

Terjadinya penurunan nilai iod tampak pada daerah serapan $3007,81 \mathrm{~cm}^{-1}$ (regangan $\mathrm{C}=\mathrm{C}$ ), sedangkan peningkatan nilai oksiran tampak pada daerah serapan 824,4 $\mathrm{cm}^{-1}$ (regangan C-O-C). Pada Gambar 3 tampak 
bahwa pemurnian meningkatkan nilai oksiran dan menurunkan nilai iod minyak jarak pagar epoksi murni. Luas daerah serapan $3007,81 \mathrm{~cm}^{-1}$ minyak jarak pagar epoksi lebih besar dibandingkan minyak jarak pagar epoksi murni, sedangkan luas daerah serapan 824,4 $\mathrm{cm}^{-1}$ minyak jarak pagar epoksi lebih kecil dibandingkan minyak jarak pagar epoksi murni.

Pemurnian juga menurunkan reaksi samping yang terbentuk pada reaksi epoksidasi minyak jarak pagar. Hal ini tampak pada daerah serapan $3466,96 \mathrm{~cm}^{-1}$ minyak jarak pagar epoksi murni lebih kecil dibandingkan minyak jarak pagar epoksi. Saremi et al. (2012) menyatakan bahwa pembentukan puncak serapan baru pada minyak kedelai epoksi di panjang gelombang $3459,8 \mathrm{~cm}^{-1}$ menunjukkan peregangangan gugus hidroksi $\mathrm{O}-\mathrm{H}$, yang mengindikasikan kemungkinan terbukanya gugus epoksi (oksiran). Hasil FTIR menunjukkan bahwa perlakuan pemurnian yang dilakukan dapat mengurangi jumlah reaksi samping yang terbentuk, sehingga nilai oksiran dan \% terepoksidasi meningkat setelah pemurnian.

\section{Karakteristik Sifat Fisik Minyak Jarak Pagar Epoksi Murni}

Karakerter sifat fisik minyak jarak pagar mengalami perubahan seiring perlakuan yang diberikan. Pada Gambar 4 (b) tampak bahwa minyak jarak pagar epoksi memiliki penampakan berwarna lebih oranye dibandingkan minyak jarak pagar (Gambar 4.a). Perubahan warna tersebut dimungkinkan akibat adanya reaksi antara minyak dengan reaktan dan katalisnya. Pemurnian minyak jarak pagar epoksi secara bertahap menggunakan aquades $\left(\mathrm{T}=30^{\circ}\right.$ dan $\left.50^{\circ} \mathrm{C}\right)$ dan larutan $\mathrm{Na}_{2} \mathrm{CO}_{3}$ $\left(\mathrm{T}=50^{\circ} \mathrm{C}\right)$ membuat sifat fisik minyak jarak pagar epoksi murni menjadi lebih jernih dibandingkan minyak jarak pagar epoksi dan hampir menyerupai tampilan fisik DOP. Karakteristik sifat fisik minyak jarak pagar epoksi disajikan pada Gambar 4.

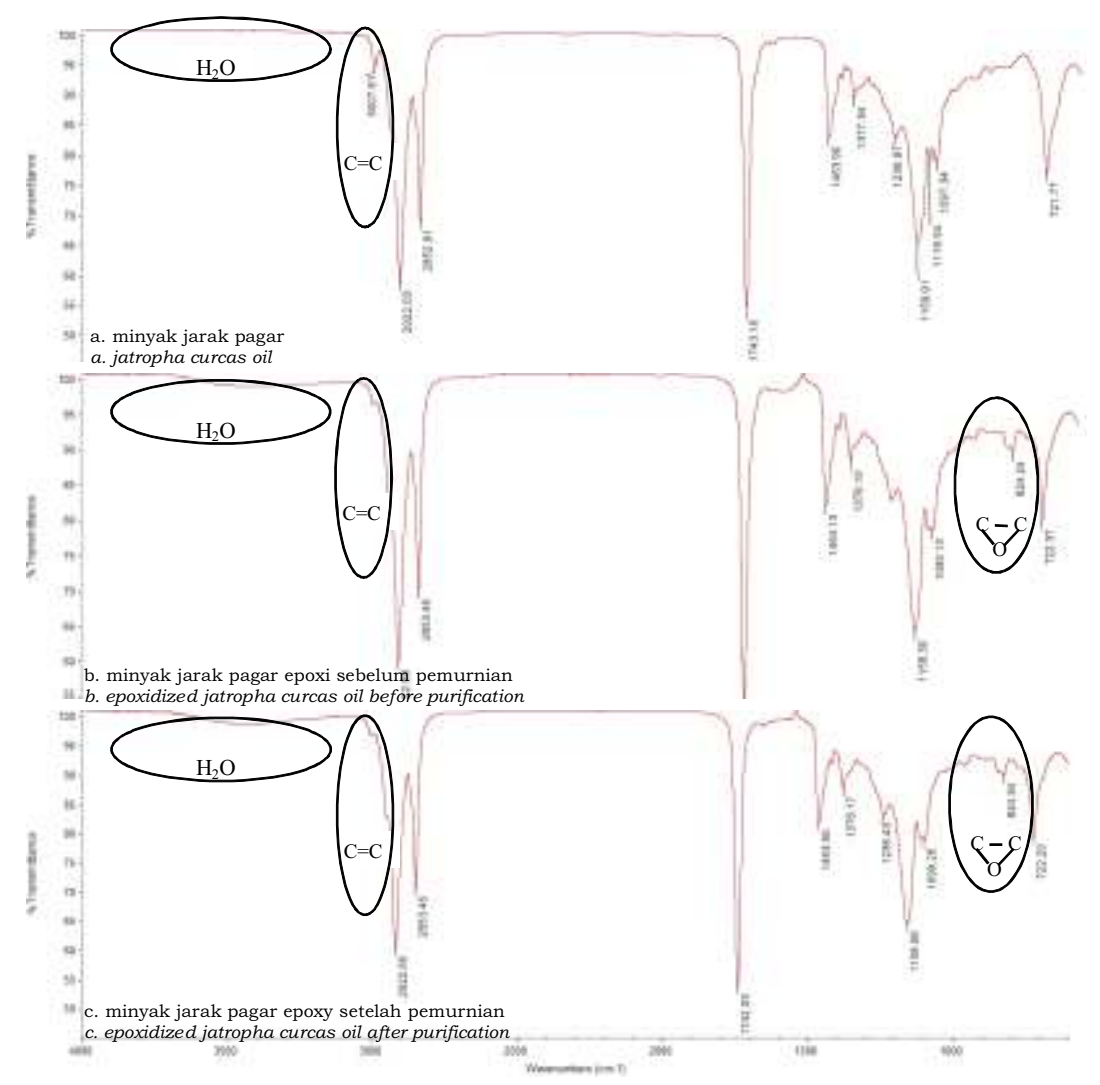

Gambar 3. Spektra FTIR minyak jarak pagar epoksi pada $60^{\circ} \mathrm{C}$ selama 7 jam reaksi Figure 3. FTIR spectra of epoxidized jatropha curcas oil at $60^{\circ} \mathrm{C}$ and 7 hours reaction 


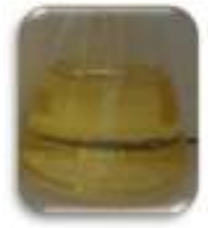

(a)

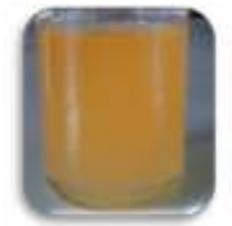

(b)

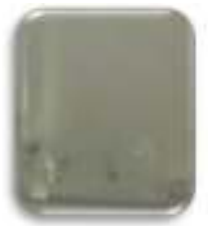

(c)

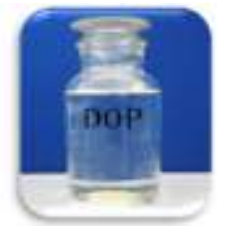

(d)

Gambar 4. (a) Minyak jarak pagar (b) Minyak jarak pagar epoksi (c) Minyak jarak pagar epoksi murni (d) DOP

Figure 4. (a) Jatropha curcas oil (b) Impurity of epoxidixed Jatropha curcas oil (c) Pure epoxidixed Jatropha curcas oil (d) DOP

\section{Karakteristik Sifat Fisik Vulkanisat Karet NBR}

Pengaruh penggunaan minyak jarak pagar epoksi terhadap kekerasan vulkanisat karet NBR disajikan pada Tabel 2 . Penggunaan minyak jarak pagar epoksi mampu menurunkan kekerasan karet NBR lebih besar dibandingkan DOP. Peningkatan kekerasan karet dipengaruhi oleh besar \% terepoksidasi minyak jarak pagar epoksi. Chandrasekara et al. (2011) menyatakan bahwa reaksi epoksidasi meningkatkan polaritas minyak nabati, sehingga ketika minyak epoksi berikatan dengan karet NBR yang bersifat polar maka akan meningkatkan pula ikatan diantaranya. Semakin kuat ikatan antara karet dan minyak maka semakin keras pula karet tersebut, sehingga nilai kekerasan vulkanisat karet meningkat. Minyak jarak pagar epoksi murni mengandung \% terepoksidasi yang lebih besar dibanding minyak jarak pagar epoksi sehingga kekerasan vulkanisat NBR kompon B lebih besar dibanding kompon A. Penurunan kekerasan juga dimungkinkan dipepengaruhi oleh kandungan asam pada minyak jarak pagar epoksi sebelum pemurnian. Reaksi samping yang bersifat asam bereaksi dengan bahan-bahan pencepat (TMTD,TBBS dan TMQ) yang bersifat basa, sehingga terjadi peregangan ikatan silang antara karet dan belerang yang menyebabkan kompon A memiliki nilai kekerasan lebih rendah dibanding kompon B.

Tegangan putus, perpanjangan putus dan ketahan sobek merupakan nilai yang menunjukkan keelastisan vulkanisat ketika diregangkan atau disobek. Semakin besar nilai kekerasannya, maka tegangan putus, perpanjangan putus dan ketahanan sobek vulkanisat karet NBR semakin menurun.
Hasil pengujian sifat fisika di atas menunjukkan bahwa vulkanisat karet NBR kompon A lebih unggul sifat tegangan putus, perpanjangan putus dan ketahanan sobek dibandingkan kompon B dan C. Hasil ini menunjukkan bahwa minyak jarak pagar epoksi mampu menggantikan pelunak DOP.

Kondisi pasca pengusangan menunjukkan bahwa kekerasan dan tegangan putus vulkanisat karet NBR mengalami peningkatan, sedangkan perpanjangan putus mengalami penurunan. Hal ini menunjukkan bahwa minyak jarak epoksi dan DOP tidak mampu bekerja sebagai heat stabilizer pada vulkanisat karet NBR. Peningkatan kekerasan terjadi akibat penguapan dan oksidasi ikatan rangkap minyak nabati selama pengusangan. Oksidasi ikatan rangkap tersebut menyebabkan berat molekul minyak menurun, sehingga vulkanisat karet menjadi semakin keras (Millan, 1959 dalam Riyanti, 1992). Morton (1963) menambahkan bahwa berat molekul pelunak yang kecil akan lebih banyak menurunkan tegangan putus dan ketahanan sobek karet. Sehingga nilai perpanjangan putus pada pengamatan menunjukkan penurunan pasca pengusangan.

Nilai modulus 200\% kompon A lebih kecil dibandingkan kompon $\mathrm{B}$ dan $\mathrm{C}$. Kecilnya nilai modulus ini dipengaruhi oleh crosslink density (Conan, 1964). Besarnya nilai \% terepoksidasi minyak jarak pagar epoksi mempengaruhi crosslink density yang terbentuk antara minyak epoksi dan karet NBR. Semakin tinggi nilai \% terepoksidasi menyebabkan minyak semakin polar dan crosslink density semakin meningkat, sehingga vulkanisat karet NBR kompon B lebih baik dari kompon A. 
Tabel 2. Sifat fisika vulkanisat karet NBR

Table 2. Physical properties of NBR vulcanizate

\begin{tabular}{|c|c|c|c|c|c|c|}
\hline \multirow{3}{*}{$\begin{array}{r}\begin{array}{c}\text { Parameter } \\
\text { Parametre }\end{array} \\
\text { Kekerasan (shore A) }\end{array}$} & \multicolumn{6}{|c|}{$\begin{array}{l}\text { Vulkanisat } \\
\text { Vulcanizate }\end{array}$} \\
\hline & \multicolumn{2}{|c|}{ A } & \multicolumn{2}{|c|}{$\mathrm{B}^{* * *}$} & \multicolumn{2}{|c|}{$\mathrm{C}^{* * *}$} \\
\hline & $55^{\star b}$ & $62^{* * c}$ & $58^{* a}$ & $67^{* b}$ & $60^{* a}$ & $70^{* * a}$ \\
\hline Tegangan putus $\left(\mathrm{N} / \mathrm{mm}^{2}\right)$ & $8,2^{* a}$ & $7,8^{* * a}$ & $7,8^{* a}$ & $8,2^{* * a}$ & $7,4^{* a}$ & $7,9^{* * a}$ \\
\hline Perpanjangan putus (\%) & $290 * a$ & $150^{* * a}$ & $250^{* b}$ & $120^{* * \mathrm{~b}}$ & $220^{* b}$ & $110^{* * b}$ \\
\hline Ketahanan sobek $\left(\mathrm{N} / \mathrm{mm}^{2}\right)$ & \multicolumn{2}{|c|}{$33,7^{a}$} & \multicolumn{2}{|c|}{$29,5^{b}$} & \multicolumn{2}{|c|}{$33,2^{\mathrm{ab}}$} \\
\hline Modulus 200\% (N/ $\left.\mathrm{mm}^{2}\right)$ & \multicolumn{2}{|c|}{$5^{c}$} & \multicolumn{2}{|c|}{$5,6^{\mathrm{b}}$} & \multicolumn{2}{|c|}{$6,3^{\mathrm{a}}$} \\
\hline Berat jenis $\left(\mathrm{g} / \mathrm{cm}^{3}\right)$ & \multicolumn{2}{|c|}{$1,183^{\mathrm{a}}$} & \multicolumn{2}{|c|}{$1,184^{a}$} & \multicolumn{2}{|c|}{$1,184^{a}$} \\
\hline $\begin{array}{l}\text { Pampatan tetap } 25 \%\left(\mathrm{~T}=30^{\circ} \mathrm{C}, \mathrm{t}=72\right. \\
\text { jam) }(\%)\end{array}$ & \multicolumn{2}{|c|}{$6,44^{a}$} & \multicolumn{2}{|c|}{$6,32^{a}$} & \multicolumn{2}{|c|}{$6,3^{a}$} \\
\hline $\begin{array}{l}\text { Pampatan tetap } 25 \%\left(\mathrm{~T}=70^{\circ} \mathrm{C}, \mathrm{t}=72\right. \\
\text { jam) }(\%)\end{array}$ & \multicolumn{2}{|c|}{$50,24^{a}$} & \multicolumn{2}{|c|}{$36,93^{b}$} & \multicolumn{2}{|c|}{$37,48^{b}$} \\
\hline
\end{tabular}

Keterangan (Remaks):

* = kondisi segera atau tanpa pengusangan (without ageing)

** = kondisi pasca pengusangan pada $100^{\circ} \mathrm{C}, 72$ jam (after ageing at $100^{\circ} \mathrm{C}, 72$ hours)

*** = Cifriadi dan Kinasih, 2013

Penggunaan minyak jarak pagar epoksi sebelum dan sesudah dimurnikan tidak mempengaruhi berat jenisnya, namun mempengaruhi sifat pampatan tetap 25\% vulkanisat karet NBR. Nilai pampatan tetap $25 \%$ kompon $\mathrm{B}$ memiliki nilai yang hampir sama dibanding kompon $\mathrm{C}$ pada suhu $30^{\circ} \mathrm{C}$ dan terendah pada suhu $70^{\circ} \mathrm{C}$. Semakin kecilnya nilai pampatannya, maka elastisitas karetnya semakin baik. Maka dari Tabel 2 diketahui bahwa penggunaan minyak jarak pagar epoksi murni dapat menggantikan DOP. Hal ini disebabkan semakin banyaknya ikatan silang dan tingginya interaksi intramolekuler dari gugus epoksi yang dimiliki minyak jarak pagar epoksi murni.

Hasil analisa statistik menggunakan uji lanjut Duncan menunjukkan bahwa perlakuan penambahan bahan pelunak yang berbeda (A, B, dan C) menunjukkan bahwa pelunak A berbeda nyata dari pelunak B dan C terhadap kekerasan (sebelum dan sesudah pengusangan), perpanjangan putus (sebelum dan sesudah pengusangan), modulus $200 \%$, dan pampat tetap $25 \%\left(\mathrm{~T}=70^{\circ} \mathrm{C}, \mathrm{t}=72\right.$ jam $)$ vulkanisat karet NBR. Namun perlakuan penambahan pelunak A pada vulkanisat karet NBR tidak berbeda nyata terhadap tegangan putus, berat jenis, dan pampat tetap $25 \%\left(\mathrm{~T}=30^{\circ} \mathrm{C}\right.$, $\mathrm{t}=72 \mathrm{jam})$. Ketahanan sobek vulkanisat karet NBR menunjukkan bahwa pengggunaan pelunak A berpengaruh nyata terhadap pelunak B dan tidak berpengaruh terhadap pelunak $\mathrm{C}$.

\section{KESIMPULAN DAN SARAN}

Hasil analisis kuantitatif dan kualitatif menunjukkan bahwa pemurnian meningkatkan kandungan nilai oksiran seiring dengan penurunan nilai iod dan hasil samping reaksi epoksidasi minyak jarak pagar epoksi. Nilai oksiran dan \%terepoksidasi tertinggi sebesar 1,94 dan $78,09 \%$. Karakteristik sifat fisik minyak jarak pagar epoksi semakin jernih setelah pemurnian dan memiliki tampilan fisik menyerupai DOP. Perlakuan pemurnian minyak jarak pagar epoksi menyebabkan penurunkan sifat fisik vulkanisat karet NBR. Maka vulkanisat karet NBR yang ditambahkan minyak jarak pagar epoksi sebelum pemurnian memiliki sifat fisik terbaik dibandingkan vulkanisat NBR yang ditambahkan minyak jarak pagar epoksi murni dan DOP.

Pengaruh reaksi samping yang bersifat asam terhadap pelunakan karet NBR perlu dikaji, seberapa banyak konsentrasi hasil reaksi samping yang mempengaruhi pelunakan karet agar hasil reaksi samping tidak mempengaruhi kualitas minyak jarak pagar epoksi. 


\section{DAFTAR PUSTAKA}

Chandrasekara, G., M. K. Mahanama, D. G. Edirisinghe and L. Karunayake. 2011. Epoxidized Vegetable Oils as Processing Aid Activators in CarbonBlack Filled Natural Rubber Compounds. J.National Science Foundation of Srilangka, 39(3): 244 250.

Cifriadi, A. dan N. A. Kinasih. 2013. Studi Minyak Jarak Pagar (Jatropha curcas L) Epoksi Sebagai Bahan Pelunak Kompon Karet NBR. Prosiding Seminar Nasional XVI Kimia dalam Pembangunan. Yogyakarta, 20 Juni 2013. Jaringan Kerjasama Kimia Indonesia.: $799-806$.

Conant, F.S. 1964. The Effect of State Cure of Vulcanizate Properties. In G. Aligger \& I. J. Sjothun (Eds). Vulcanization of Elastomer. Reinhold Publishing Co.New York, USA

Gall, R. J. and F. P. Greenspan, 1958. Vinyl Epoxy Plasticizers. J. Industrial and Engineering Chemistry 50(6): 865-867

Gamage, P. K., M. O'Brien, and L. Karunanayake. 2009. Epoxidation of Some Vegetable Oils and Their Hydrolised Products with Peroxyformic Acid-Optimised to Industrial Scale. $J$. Natn Sci. Foundation Srilanka 37(4): $229-240$.

Gan, L. H, K. S. Ooi, S. H. Goh, L. M. Gan, and Y. C. Leong. 1994. Epoxsidized Esthers of Palm Olein as Plasticizers for Poly(Vinyl Chloride). J. Eur.Polym 31(8): $719-724$.

Greco, A, D. Brunetti, G. Renna, G. Mele, and A.Maffezzoli, 2010. Plasticizer for Poly(Vinyl Chloride) from Cardanol as a Renewable Resource Material. J. Polymer Degradation and Stability 95: 2169-2174.

Hawash, S., G. El Diwani and E. Abdel Kader. 2011. Optimization of Biodiesel Production of Jatropha Oil By Heterogeneous Base Catalysed Transesterification. International J. of Engineering Science and Technology 0975-5462 (3): 5242 - 5251.
Karaukoph, L. G. and A. Goodwin. 2005 Plasticizersin: Charles, E.W., C.A. Daniels, J.W. Summer. PVC Handbook. Carl Hansen Verlag, Munich.

Karmalm, P., T. Hjertberg, A. Jansson, and R. Dahl, 2009. Thermal Stability of Poly(Vinyl Chloride) with Epoxidised Soybean Oil as Primary Plasticizer. J. Polymer Degradation and Stability 94: 2275-2281.

Petrovic, Z. S., A. Zlatanic, C. C. Lava, and F. S. Sinadinovic, 2002. Epoxidation of Soyabean Oil in Toluene with Peroxoacetic and Peroxiformic AcidKinetics and Side Reaction. Europian J. of Lipid Science and Technology. 104: 293-299.

Pérez J. D. E. P., D. M. Haagenson, S. W. Priyor, C. A. Ulven, and D. P. Wiensenborn, 2009. Production and Characterization of Epoxidized Canola Oil. American Society of Agricultural and Biological Engineers 52 (4): 12891297.

Riyanti, N. 1992. Minyak Epoksi dari CPO Sebagai Processing Aid Pada Pembuatan Barang Jadi Karet NitrilButadiena-PVC. Skripsi. Departemen Teknologi Industri Pertanian Fakultas Teknologi Pertanian Institut Pertanian Bogor, Bogor

Saremi, K., T. Tabarsab, A. Shakeric, and A. Babanalbandi. 2012. Epoxidation of Soyabean Oil. Annals of Biological Research 3(9): $4254-4258$.

Saefurohman, A. 2008. Epoksida Minyak Jarak Pagar sebagai Pemlastis Film Polivinil Klorida. Tesis. Sekolah Pasca Sarjana Institut Pertanian Bogor, Bogor

Tullo, H. A. 2005. Cutting Out Phatalates Polyvinyl Chloride Applications Haven't Been Flexible Enough to Accept Alternatives to Phatalate Esthers. Chem and Eng News 83: 2931. 